Provided for non-commercial research and education use. Not for reproduction, distribution or commercial use.

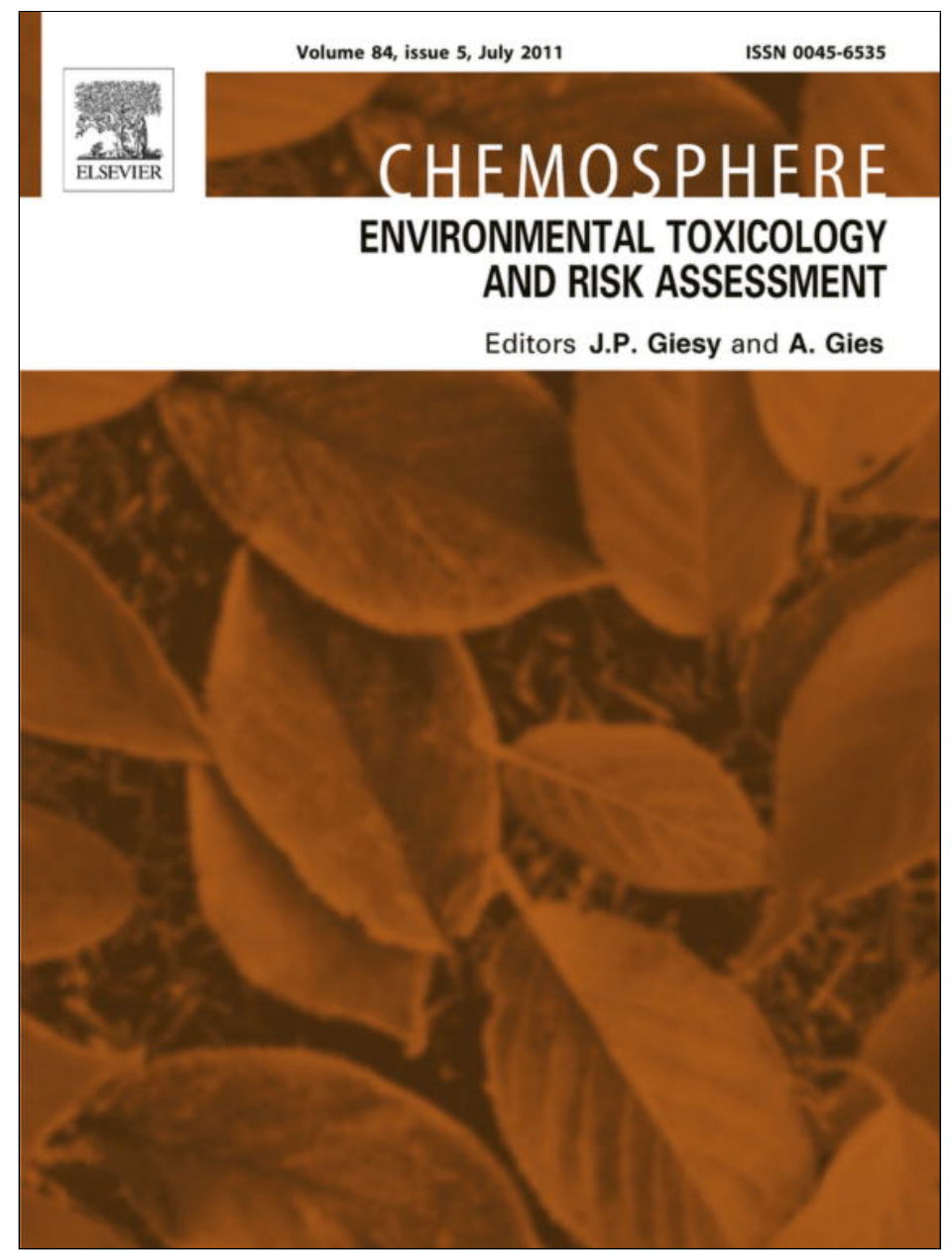

This article appeared in a journal published by Elsevier. The attached copy is furnished to the author for internal non-commercial research and education use, including for instruction at the authors institution and sharing with colleagues.

Other uses, including reproduction and distribution, or selling or licensing copies, or posting to personal, institutional or third party websites are prohibited.

In most cases authors are permitted to post their version of the article (e.g. in Word or Tex form) to their personal website or institutional repository. Authors requiring further information regarding Elsevier's archiving and manuscript policies are encouraged to visit:

http://www.elsevier.com/copyright 


\title{
Determinants of exposure to mercury in hair from inhabitants of the largest mercury mine in the world
}

\author{
Sergi Díez ${ }^{\mathrm{a}, *}$, José M. Esbrí ${ }^{\mathrm{b}}$, Aurelio Tobias ${ }^{\mathrm{c}}$, Pablo Higueras ${ }^{\mathrm{b}}$, Alba Martínez-Coronado ${ }^{\mathrm{b}}$ \\ ${ }^{a}$ Environmental Chemistry Department, IDAEA-CSIC, Jordi Girona, 18-26, 08034 Barcelona, Spain \\ ${ }^{\mathrm{b}}$ Dept. Ingeniería Geológica y Minera, Laboratorio de Biogeoquímica de Metales Pesados, Universidad de Castilla-La Mancha. EUP Almadén. Pl. Manuel Meca, 1, \\ 13400 Almadén (Ciudad Real), Spain \\ ${ }^{\mathrm{c}}$ Geosciences Department, IDAEA-CSIC, Jordi Girona, 18-26, 08034 Barcelona, Spain
}

\section{A R T I C L E I N F O}

\section{Article history:}

Received 7 September 2010

Received in revised form 3 March 2011

Accepted 31 March 2011

Available online 27 April 2011

\section{Keywords:}

Mercury

Hair

Mercury mining

Almadén

Fish consumption

Spain

\begin{abstract}
A B S T R A C T
Mercury exposure of the local population was assessed in two areas of the Almadén mercury mining district, Spain, which has been the world's largest producer of this element. Two groups, who are exposed to different sources of mercury, from a point source in Almadén and a diffuse source hundreds of kilometres away in the same region, were studied. Total mercury (THg) in human hair ranged from 0.20 to $9.35 \mathrm{mg} \mathrm{kg}^{-1}$ and the mean value was $2.64 \mathrm{mg} \mathrm{kg}^{-1}$. About $87 \%$ of subjects had $\mathrm{THg}$ levels in excess of the EPA reference dose $\left(\mathrm{RfD}=1.0 \mathrm{mg} \mathrm{kg}^{-1}\right)$, while a high percentage $(68 \%)$ of them live in Almadén. There was a clear increase in hair Hg with reported fish consumption and the highest mean hair mercury level was 4 times the RfD in a group who had reported the highest consumption of fish. For the whole group, there was a significant effect of age, gender and fish consumption in relation to $\mathrm{Hg}$ concentration in the hair. Nevertheless, when both groups were tested separately by means of a multivariate regression model, there was significant exposure in those living near the mine area. Several factors such as age, gender and fish consumption remained statistically significant and were associated with THg. The main conclusion is that people living close to the hot spot are more impacted by mercury than people living further away. The intake of $\mathrm{Hg}$ through consumption of fish is an important parameter for $\mathrm{Hg}$ exposure; however, in the case of people living close to the hot spot, their levels are related to the highly Hg-impacted living environment.
\end{abstract}

(c) 2011 Elsevier Ltd. All rights reserved.

\section{Introduction}

Almadén, located in the Castilla-La Mancha region (southcentral Spain), is a world-famous town because the local mercury mining district has produced one third of the total mercury produced by mankind in historic times (Hernández et al., 1999). This district comprises a number of mercury mines, the largest one being located just under the town. For this reason, the town inhabitants have suffered intense exposure to mercury vapours, coming from the very close mining and metallurgical facilities (Higueras et al., 2006). Especially important has been mercury exposure among miners, active until the closure of the mines and the metallurgical plant in 2003 , although with a limited work schedule since 1950 ( $8 \mathrm{~d}$ a month, with $6 \mathrm{~h}$ per day).

In the Almadén area, a number of studies have been carried out involving the presence of mercury in edible biological species: Moreno et al. (2005) reported mercury contents of $8-10 \mathrm{mg} \mathrm{kg}^{-1}$ in hair from pigs living in a decommissioned mercury metallurgic

\footnotetext{
* Corresponding author. Tel.: +34 93 4006100; fax: +34 932045904

E-mail address: sdsqam@cid.csic.es (S. Díez).
}

precinct, eating mercury-contaminated vegetation and inhaling mercury-rich air (Martínez-Coronado et al., 2010); Molina et al. (2006) analysed wild plant species from the mining district, finding concentrations in the range $0.13-2695 \mathrm{mg} \mathrm{kg}^{-1} \mathrm{THg}$, including edible plants such as Asparagus acutifolius; and Higueras et al. (2006) reported mercury concentrations of up to $9 \mathrm{mg} \mathrm{kg}^{-1}$ and $26 \mathrm{mg} \mathrm{kg}^{-1}$ in the muscle and hepatopancreas, respectively, of the red swamp crayfish Procambarus clarkii, a commonly consumed freshwater food in the region. Nevertheless, little information is available on mercury exposure and its potential health effects in this population. On the other hand, Castilla-La Mancha region is one of the poorest in Spain, with a quite low industrialization level. Possible mercury emissions different from Almadén only may came from four industries scattered along the region, and declaring a total of $0.34 \mathrm{Mg} \mathrm{Hg}$ per year in 2009 (PRTR, 2011).

Scalp hair has frequently been used as a biomarker for evaluating methylmercury (MeHg) exposure in dietary habits (McDowell et al., 2004), since this organic form is incorporated into hair follicles (by the formation of a MeHg-cysteine complex) in proportion to its content in blood. The hair-to-whole blood ratio in humans has been estimated to be about 250 to 1 (WHO, 1990). Because this 
MeHg-cysteine complex is stable (Phelps et al., 1980; WHO, 1990) and hair grows at an approximate rate of about $1 \mathrm{~cm} \mathrm{month}^{-1}$, then certain studies can be performed to determine past exposures. Because the half-life of $\mathrm{MeHg}$ in the body is about 1.52 months (Smith and Farris, 1996), the hair nearest the scalp best reflects current exposures and recent blood concentrations (Díez, 2009).

On the other hand, mercury contents in hair seem to be more related to dietary constraints, in particular to fish consumption (Johnsson et al., 2004). It is generally accepted that the consumption of contaminated fish is the primary route of exposure to $\mathrm{MeHg}$ for humans and wildlife, although few studies (Aks et al., 1995; Horvat et al., 2003; Montuori et al., 2006) show that other sources of $\mathrm{Hg}$ should be seriously considered in particular areas.

To assess the risk of mercury exposure in a population, information is needed on its likely route. On the assumption that fish consumption is a well-accepted source of mercury, but with the hypothesis that living near a high Hg-impacted area should contribute to increased mercury levels in the human body, THg levels in hair were determined in a selected group of residents in the area of Almadén in south-central Spain, which is the world's largest mercury mining region. Mercury exposure in the hair of the local population was assessed in two areas where the people are exposed to different sources of mercury: a point source in Almadén district and surroundings (ALM) and a diffuse source hundreds of kilometres away in the same region (CLM).

The aim of this study was to perform a preliminary evaluation on the presence of mercury in the hair of inhabitants in the Almadén area, to determine the most important determinant of exposure to the organic forms of the element (e.g. fish consumption and/or area of residence). Potential factors such as age and gender were also assessed.

\section{Materials and methods}

The study was conducted in the Almadén mining area and municipalities from the Castilla-La Mancha region located within a range between 50 and 300 kilometres away from the first (e.g. Ciudad Real and Albacete cities) (Fig. 1), from October 2005 to March 2006. A comparison between both geographical groups was made to identify the factors most likely to contribute to $\mathrm{Hg}$ levels in hair. The influence of potential factors, besides area of residence, such as age, gender or fish diet was also determined using statistical methods.

\subsection{Population study}

Individuals (aged 5-88) were selected randomly and the objectives and methods of the study were described to them. All the subjects agreed to participate and gave their consent. Most of the study participants appeared to be healthy and no had major congenital anomalies. We recruited 170 individuals, of whom 70 (41.2\%) were males and 100 (58.8\%) females. A questionnaire (a copy is available upon request from the corresponding author) was prepared to collect data on the age, gender, occupation and place of residence during the last nine months and frequency of fish consumption. Thereafter, the participants were asked about a number of aspects related to fish consumption, including the number of fish meals consumed per week. They were also asked about how often they consumed fish during the last 4 months with the following options: never, 1-2 times per week, 3-4 times per week, 5-6 times per week, once per day or more. No respondent reported fish consumption more than once per day. Since hair grows approximately $1 \mathrm{~cm} \mathrm{month}^{-1}$ (Cernichiari et al., 1995) and in order to determine the exposure during the last 4 months, $4 \mathrm{~cm}$ of hair, corresponding to 4-5 months of growth, were taken.

Study participants were divided into two groups: (a) the Almadén area group (ALM) made up of 108 subjects (64 females and 44 males); and (b) the group of people living at municipalities located away from the hot spot (CLM) constituting 62 subjects ( 36 females and 26 males).

\subsection{Analytical procedure}

Hair strands approximately $4 \mathrm{~cm}$ long were obtained from the root in the occipital region. The samples were coded and stored in sealed plastic bags until analysis for THg. Each sample was homogenised and analysed by Zeeman absorption atomic spectrometry (ZAAS) (Sholupov and Ganeyev, 1995), using a Lumex

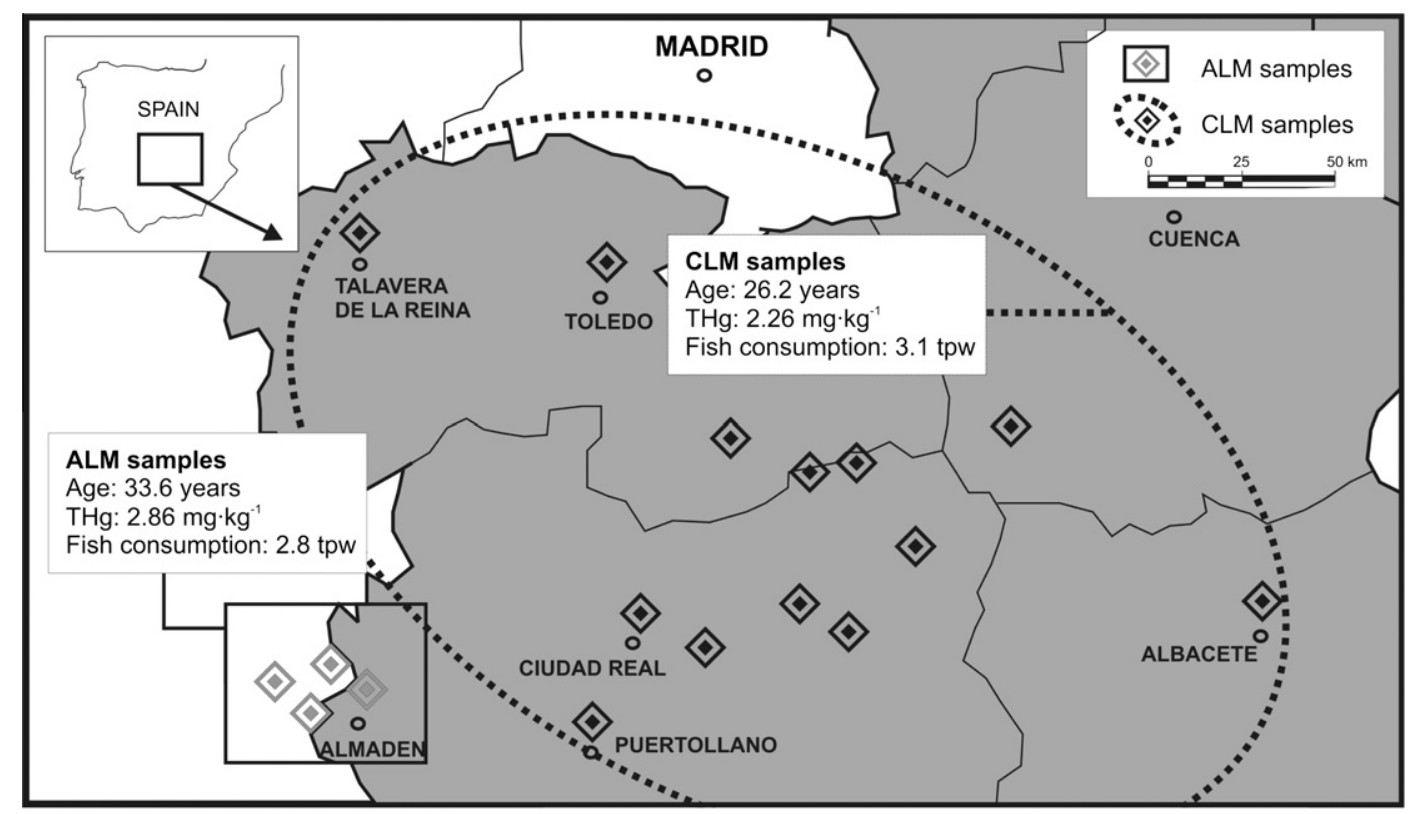

Fig. 1. Geographical area under study and situation of the main sampling sites. Map shows mean age, mean THg in hair and fish consumption (in times per week, tpw). Shadowed: provinces belonging to the Castilla-La Mancha region. 
RA-915 + with a pyrolysis attachment. The detection limit of this technique was $5 \mathrm{ng} \mathrm{g}^{-1}$.

The accuracy of this method was assessed by certified reference material from NCS Beijing, China (NCS ZC81002b) containing $1.06 \pm 0.26 \mathrm{mg} \mathrm{kg}^{-1}$ of THg. Each sample was analysed in triplicate.

\subsection{Statistical methods}

Mercury concentrations were tested for normality and were found to be not normally distributed; the data were therefore log-transformed. The differences between the groups were tested for significance using the Mann-Whitney $U$ non-parametric test. Statistical significance was defined as $p \leqslant 0.05$. Simple and multiple linear regression analysis to assess the relationship between mercury concentrations and covariates were used. Statistical analyses were done using SPSS, version 15 for Windows (SPSS Inc., Chicago, IL).

\section{Results}

\subsection{Population study}

The descriptive statistics on the $\mathrm{Hg}$ concentrations in hair for men and women in ALM, CLM and the whole group are given in Table 1 . The mean age of these individuals was $30.9(S D=17.4)$, the youngest being 5 years old and the oldest 88 years old. No significant differences between men and women groups were obtained for age, although women were slightly younger than men (30.9 vs. 31.0 years; $p=0.948$ ). On the other hand, the frequency of fish consumption between genders was not significantly different $(p=0.395)$. Median meals for men and women were the same (2.80 meals per week). Even when the whole group was assessed separately, no significant differences between men and women were obtained for frequency of fish consumption (2-3 vs. $2-3$ times per week).

The two groups, ALM (2.86 $\left.\mathrm{mg} \mathrm{kg}^{-1}\right)$ and CLM (2.26 $\left.\mathrm{mg} \mathrm{kg}^{-1}\right)$, were significantly different in $\mathrm{THg}(U=2383 ; p=0.002)$. Furthermore, significant differences in $\mathrm{THg}$ were found between males and females (Fig. 2). Men had higher mean hair $\mathrm{Hg}\left(3.15 \mathrm{mg} \mathrm{kg}^{-1}\right.$ ) than women $\left(2.28 \mathrm{mg} \mathrm{kg}^{-1}\right)(U=2556 ; p=0.003)$, for the whole group. Similar findings were reached when the two groups were tested separately (ALM men $(n=44): 3.31 \mathrm{mg} \mathrm{kg}^{-1}$ vs. women $(n=64): 2.55 \mathrm{mg} \mathrm{kg}^{-1}$; CLM men $(n=26): 2.89 \mathrm{mg} \mathrm{kg}^{-1}$ vs. women $\left.(n=36): 1.81 \mathrm{mg} \mathrm{kg}^{-1}\right)$. No significant differences between ALM and CLM groups were obtained for frequency of fish consumption ( $U=694 ; p=0.479)$, and the median value for ALM group was lower (2.76 meals per week) than from CLM (3.13 meals per week).

Table 1

Concentrations of $\mathrm{THg}\left(\mathrm{mg} \mathrm{kg}^{-1}\right)$ in the hair of studied participants with the description of variables of interest by area of residence.

\begin{tabular}{|c|c|c|c|c|}
\hline & & \multirow[b]{2}{*}{$\begin{array}{l}\text { Total } \\
(n=170)\end{array}$} & \multicolumn{2}{|l|}{ By area } \\
\hline & & & $\begin{array}{l}\text { ALM } \\
(n=108)\end{array}$ & $\begin{array}{l}\text { CLM } \\
(n=62)\end{array}$ \\
\hline \multicolumn{5}{|l|}{ Gender } \\
\hline Females & $n(\%)$ & $100(58.8)$ & $64(59.3)$ & $36(58.1)$ \\
\hline Males & $n(\%)$ & $70(41.2)$ & $44(40.7)$ & $26(41.9)$ \\
\hline \multicolumn{5}{|l|}{ Age } \\
\hline In years & Mean (sd) & $30.9(17.4)$ & $33.6(18.8)$ & $26.2(13.3)$ \\
\hline \multicolumn{5}{|l|}{$\mathrm{THg}$} \\
\hline In $\mathrm{mg} \mathrm{kg}^{-1}$ & Mean (sd)/ & $2.64(1.67) /$ & $2.86(1.56) /$ & $2.26(1.80) /$ \\
\hline & median & 2.32 & 2.51 & 1.79 \\
\hline \multicolumn{5}{|l|}{ Fish consumption } \\
\hline In times per week & $\begin{array}{l}\text { Mean }(\mathrm{sd}) / \\
\text { median }\end{array}$ & $2.8(1.5) / 3$ & $2.8(1.4) / 3$ & $3.1(1.6) / 3$ \\
\hline
\end{tabular}

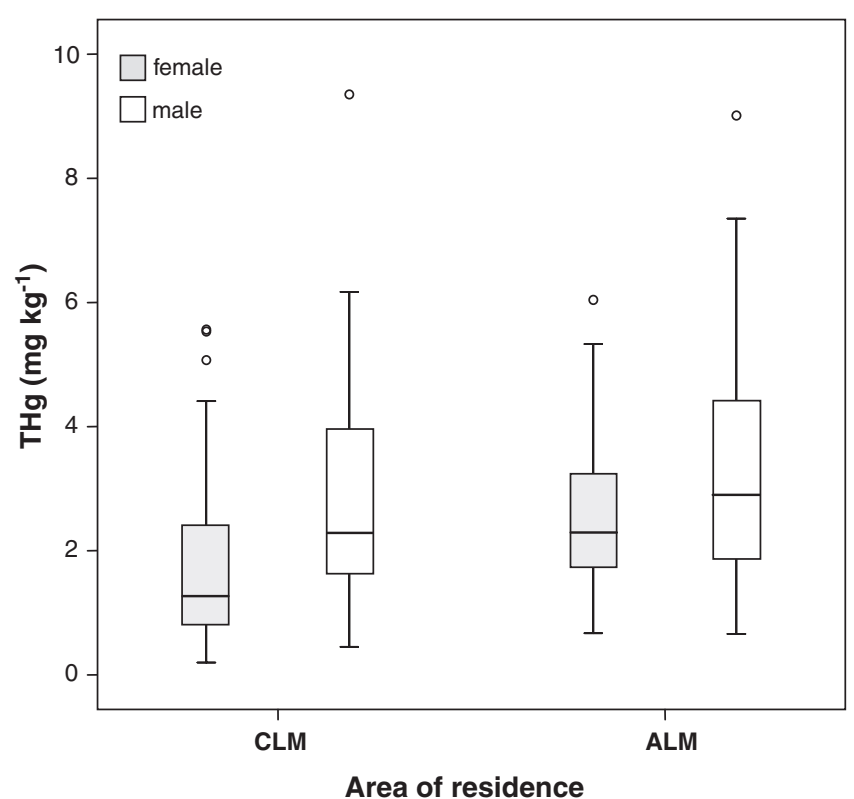

Fig. 2. Box plot of the concentration of total mercury (THg) in hair by gender in relation to area of residence.

Within the female group ( $n=100)$, the women of child-bearing age (16-49 years) $(n=76)$ had a mean hair mercury level of $2.12 \mathrm{mg} \mathrm{kg}^{-1}$ (range $0.20-5.56$ ). The two groups of women of child-bearing age, ALM (2.44 $\left.\mathrm{mg} \mathrm{kg}^{-1}\right)$ and CLM $\left(1.73 \mathrm{mg} \mathrm{kg}^{-1}\right)$ were significantly different in $\mathrm{THg}(U=423 ; p=0.002)$.

\subsection{Mercury and fish consumption}

The THg levels stratified in accordance with the frequency of fish consumption are presented in Fig. 3. Only a 3\% of the subjects did not eat fish in the past half year, since only five respondents reported that never ate fish. Fish was consumed at least once by $97 \%$, from 2 to 3 times a week by $58 \%$, and a $15 \%$ of the respondents corresponded to heavy consumers ( $\geqslant 4$ times a week). As expected, there was a marked increase in hair THg with reported fish consumption. The median mercury level in hair was $2.32 \mathrm{mg} \mathrm{kg}^{-1}$ for the whole group and $4.11 \mathrm{mg} \mathrm{kg}^{-1}$ for those who reported the highest consumption of fish. The median mercury level in the group with the highest fish consumption was almost 1.8 times higher than the median of the group that rarely or never ate fish. Significant differences in THg $(p<0.05)$ were found between both groups. Frequency of fish consumption was classified into three categories: category 1 : never or once a week; category 2: 2-3 times per week and category 3: equal or more than 4 times per week. Hence, there was a statistically significant difference between categories 1 and $3(U=147 ; p=0.002)$ and 2 and $3(U=596$; $p=0.002)$, but not between 1 and $2(U=600 ; p=0.235)$. Moreover, when the groups where tested separately and categorised, categories 1 and $3(U=135 ; p=0.035)$ and 2 and $3(U=519 ; p=0.055)$ were marginally significantly different from each other at ALM.

There was a positive correlation and consequently a strong relationship between the consumption of fish and $\mathrm{THg}$ in the whole group tested or even when the groups were analysed individually. Fig. 3 clearly shows that THg in hair significantly increased as the number of fish meals rose.

\subsection{Linear regression analysis}

In order to assess the relationship between $\mathrm{Hg}$ concentrations in hair and explanatory variables such as age, gender, area of residence and fish consumption, we first used simple linear regression 


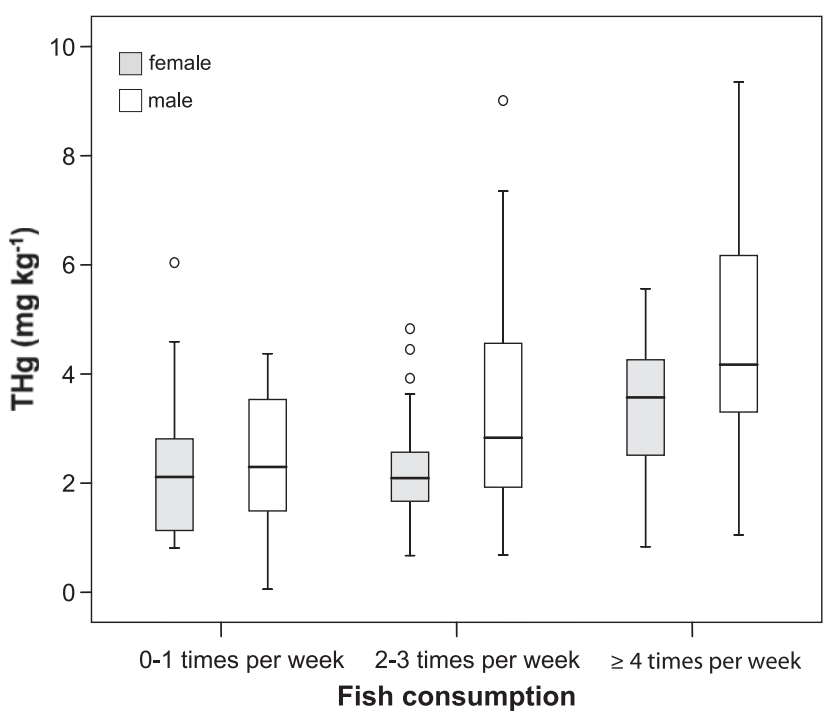

Fig. 3. Box plot of the concentration of total mercury $(\mathrm{THg})$ in hair by gender in relation to total consumption of fish.

models. As seen in Table 2, for the simple linear regression models, the area of residence was significantly related with THg concentrations, with $40 \%(\beta=0.400)$ higher concentrations in ALM than in CLM $(p<0.001)$. Additionally, THg levels were $33 \%$ times higher in males ( $\beta=0.334, p=0.002)$; for an increase of one year of age THg levels increased $1 \%(\beta=0.010, p=0.002)$ and also for an increase of a fishmeal per week, THg increased $12 \%(\beta=0.123$, $p=0.001$ ).

In the next step, all variables were adjusted for a multiple linear regression model to evaluate their coexisting effects on THg levels (Table 2). It can be observed that estimates for gender $(\beta=0.288)$, age $(\beta=0.006)$ and fish consumption $(\beta=0.122)$ did not differ substantially from simple linear regression models, remaining statistically significant ( $p=0.005, p=0.036$ and $p=0.001$, respectively). However, when adjusting for all those variables, surprisingly, the estimate effect for the area of residence decreased dramatically ( $\beta=0.051)$ as was not statistically significant $(p=0.738$ ).

Finally, multiple linear regression models were fitted separately according the area of residence (Table 3 ). Similar estimates for gender and age were found in both areas although these effects on $\mathrm{THg}$ levels were only statistically significant in ALM. Although fish consumption was statistically related with $\mathrm{THg}$ levels in both areas $(p=0.032$ in ALM and $p<0.001$ in CLM), the effect for an increase of a fishmeal per week was higher in CLM ( $\beta=0.357$ ) than in ALM $(\beta=0.082)$. Furthermore, mean-log levels of THg for the baseline reference group, i.e. females with mean age of 30.9 years who do not eat fish, were higher in ALM $(\alpha=0.564)$ than in CLM $(\alpha=-0.217)$

Table 2

Simple and multiple linear regression analysis (coefficients $(\beta)$ and its standard errors (SE), and $p$ values) for concentrations of THg in hair.

\begin{tabular}{llllll}
\hline & \multicolumn{1}{l}{ Simple } & & & Multiple & \\
\cline { 2 - 3 } & $\beta(\mathrm{SE})$ & $p$-value & & $\beta(\mathrm{SE})$ & $p$-value \\
\hline $\begin{array}{l}\text { Area } \\
\text { ALM }\end{array}$ & $0.400(0.108)$ & $<0.001$ & $0.051(0.151)$ & 0.738 \\
$\begin{array}{l}\text { Gender } \\
\text { Males }\end{array}$ & $0.334(0.107)$ & 0.002 & $0.288(0.102)$ & 0.005 \\
$\begin{array}{l}\text { Age } \\
\text { In years }\end{array}$ & $0.010(0.003)$ & 0.002 & $0.006(0.003)$ & 0.036 \\
$\begin{array}{l}\text { Fish consumption } \\
\text { In times per week }\end{array}$ & $0.123(0.035)$ & 0.001 & $0.122(0.034)$ & 0.001 \\
\hline
\end{tabular}

Table 3

Multiple linear regression analysis (constant $(\alpha)$ and slope coefficients $(\beta)$ and its standard errors (SE), and $p$ values) for concentrations of THg in hair, by area of residence (Almadén, ALM and Castilla-La Mancha, CLM).

\begin{tabular}{llllll}
\hline & ALM & & & \multicolumn{2}{l}{ CLM } \\
\cline { 2 - 3 } \cline { 5 - 6 } & $\beta(\mathrm{SE})$ & $p$-value & & $\beta(\mathrm{SE})$ & $p$-value \\
\hline $\begin{array}{l}\text { Constant }(\alpha) \\
\begin{array}{l}\text { Gender } \\
\text { Males }\end{array}\end{array}$ & $0.564(0.129)$ & $<0.001$ & & $-0.217(0.218)$ & 0.341 \\
$\begin{array}{l}\text { Age } \\
\text { In years }\end{array}$ & $0.270(0.110)$ & 0.016 & $0.252(0175)$ & 0.179 \\
$\begin{array}{l}\text { Fish consumption } \\
\text { In times per week }\end{array}$ & $0.005(0.003)$ & 0.056 & $0.005(0.005)$ & 0.345 \\
\hline
\end{tabular}

\section{Discussion}

The present study assessed the exposure to mercury in the hair of a population from two areas of south-central Spain; one was Almadén, which is the world's largest mercury mining region in the world, and the second was the general population from the enclosing region (CLM). Both groups are exposed to different sources of mercury depending on the area of residence: a point source in Almadén and a diffuse source on the region-scale surroundings.

Over the last decades, several studies have suggested that mercury exposure due to fish consumption is the main factor that contributes to body burden mercury levels. Therefore, a fish diet is considered as an effective predictor of mercury and a major route through which mercury is accumulated, especially in subjects with no occupational exposure (Holsbeek et al., 1996; Johnsson et al., 2004, 2005; McDowell et al., 2004; Morrissette et al., 2004; Bjornberg et al., 2005; Babi et al., 2000).

As a result, different guidelines and recommendations have been proposed by committees, governments and/or administrations. According to a World Health Organisation (WHO) report, based on neurotoxicity data from Japan and Iraq (WHO, 1990), the no observed adverse effect level (NOAEL) for $\mathrm{Hg}$ in adults is $50 \mathrm{mg} \mathrm{kg}^{-1}$ dry wt of hair. Later on, Harada et al. (1999) reported that the upper limit of a normal hair $\mathrm{Hg}$ level is $10 \mathrm{mg} \mathrm{kg}^{-1}$ dry wt., whereas Grandjean et al. $(1997,1999)$ showed that Hg-related neuropsychological dysfunctions were present in children even with $\mathrm{Hg}$ levels below $10 \mathrm{mg} \mathrm{kg}^{-1}$ dry wt in maternal hair in the Tapajos River basin, Brazil and in the Faroe Islands, Denmark. In 2001, based on studies in Faroe, New Zealand, and the Seychelles, the US Environmental Protection Agency (USEPA, 2001, 2010) adopted a revised reference dose (RfD) for $\mathrm{MeHg}$ of $0.1 \mu \mathrm{g}$ mercury per $\mathrm{kg}$ body weight per day. This RfD was based on neurodevelopmental effects associated with in utero exposure to $\mathrm{MeHg}$ from the maternal diet and is related to a maternal hair mercury concentration of $1.0 \mathrm{mg} \mathrm{kg}^{-1}$ (NRC, 2000).

Interestingly, the women of child-bearing age (16-49 years) $(n=76)$ had a mean hair mercury level of $2.12(0.20-5.56)$. Then, above $87 \%$ of this group monitored in the present study exhibited hair mercury levels above the RfD advisory level, while a 63\% corresponded to the ALM group.

Among all hair samples, none of our subjects had levels of mercury greater than the NOAEL. On the other hand, 63\% $(n=107)$ of them had $\mathrm{Hg}$ concentrations greater than $2.0 \mathrm{mg} \mathrm{kg}^{-1}$ in hair (the WHO "normal" level), while $75 \%(n=80)$ of these corresponded to inhabitants living in ALM.

A review of the literature (Table 4) suggests that gold mining and fish consumption constitute the most important sources of mercury contamination that affect people in the world. Mercury contamination from abandoned $\mathrm{Hg}$ mines (Li et al., 2009), in $\mathrm{Hg}$ recycling operations (Gibb et al., 2008) and by the Hg used in gold 
amalgamation at mining sites (Barbosa et al., 2001; Drasch et al., 2001; Barbieri et al., 2009) is a great environmental concern around the world. Previous studies have found that coastal populations commonly exhibit higher levels of $\mathrm{Hg}$ than inland populations, most likely as a result of higher fish and seafood consumption (Knobeloch et al., 2005; Mahaffey, 2005).

The mean THg levels in ALM and CLM (Table 4) were lower than those reported for populations with high fish consumption, such as the Seychelles Islands (Myers et al., 2000), the Faroe Islands (Grandjean et al., 1997), the Madeira Island (Renzoni et al., 1998), the Amazon basin (Barbosa et al., 2001), Tunisia (MezghaniChaari et al., 2010) or Japan (Endo and Haraguchi, 2010). On the other hand, Spanish inhabitants of the Almadén area exhibited higher THg levels than studies from the USA (McDowell et al., 2004; Karouna-Renier et al., 2008), European countries such as Albania (Babi et al., 2000), Germany (Pesch et al., 2002), Greece (Gibicar et al., 2006), Italy (Díez et al., 2008), Portugal (Reis et al., 2009), Sweden (Gerhardsson and Lundh, 2010) or Slovenia (Miklavčič et al., 2011) and other Spanish cities (Batista et al., 1996; Montuori et al., 2006; Díez et al., 2009; Freire et al., 2010).

Despite the fact that fish consumption could be considered as one of the most significant predictors of $\mathrm{THg}$, especially in adult heavy consumers, other studies have shown exposure of $\mathrm{Hg}$ via consumption of $\mathrm{Hg}$-contaminated food and inhalation (Horvat et al., 2003), and via working in or living near mercury-related industries (Aks et al., 1995) and chlor-alkali plants (Montuori et al., 2006). Our results support the findings of those earlier studies, indicating that the concentration of $\mathrm{Hg}$ found in hair is dependent on dietary intake, but in populations settled near mercury activities (e.g. mining, chlor-alkali) their mercury contribution to body burden rises.

Earlier studies showed that gender is unlikely to play a role in determining mercury accumulation in hair (Kosatsky et al., 2000;
Mortada et al., 2002; Olivero et al., 2002). Nevertheless, in our study, males were found to have a higher mean value of mercury content in hair than females. Moreover, these differences were significant $(p=0.000)$. Similar findings were reported elsewhere in Amazonian populations (Malm et al., 1995; Lebel et al., 1996), Japan (Nakagawa, 1995) and Italy (Díez et al., 2008), whereas contradictory findings have been reported in Spain (Batista et al., 1996; Montuori et al., 2006) and Albania (Babi et al., 2000).

Consumption patterns depend on meals consumed and on serving sizes, and it has been described that this could account for gender-related differences (Lebel et al., 1997; Burger, 2000, 2005; Díez et al., 2009). As described above, since consumption of fish is well-known as the main factor that contributes to body burden mercury, it should be possible to find a positive correlation between the number of meals per week and the increase of $\mathrm{Hg}$ in hair. In our study, this hypothesis was not fulfilled because the mean concentrations of THg in males were higher than in females, even though the reported fish meals for men were slightly lower than for women. This may indicate either that males might consume more fish per serving or that in females the $\mathrm{Hg}$ could be eliminated as a result of different hair treatments such as artificial hair waving and hair colouring/dyeing (Dakeishi et al., 2005; Knobeloch et al., 2007).

We further examined interesting differences between the two areas studied. Gender and age were analogous between both groups with very similar estimates. Fish consumption was also associated with $\mathrm{THg}$ concentrations, although in ALM the increase was $8 \%$ of THg per unit of fishmeal a week versus an increase of $36 \%$ in CLM. However, the baseline median mercury levels in the scalp hair of inhabitants in ALM were nearly 1.5-fold higher compared with people living in CLM. This evidence suggests that the area of residence leads to much higher levels of THg in ALM (0.564) than in CLM. For this reason, the intake of $\mathrm{Hg}$ through

Table 4

THg concentrations $\left(\mathrm{mg} \mathrm{kg}^{-1}\right)$ in human hair from different exposed populations worldwide.

\begin{tabular}{|c|c|c|c|c|}
\hline Location & Mean & Range & Remarks & References \\
\hline Tarragona, Spain & 0.77 & $0.18-2.44$ & School children & Batista et al. (1996) \\
\hline Faroe islands, Denmark & 4.27 & $2.6-7.7$ & Mother at parturition & Grandjean et al. (1997) \\
\hline Madeira, Portugal & 10.39 & $1.93-42.61$ & Pregnant women & Renzoni et al. (1998) \\
\hline Albania & 0.71 & $0.195-1.96$ & Adults, $20-56$ yr old & Babi et al. (2000) \\
\hline \multirow[t]{2}{*}{ Seychelles islands } & 6.80 & $0.5-26.7$ & Maternal hair & Myers et al. (2000) \\
\hline & 6.50 & $0.9-25.8$ & 5-6 yr old children & \\
\hline Diwalwal, Philippines & 2.70 & $0.03-37.76$ & Gold-mining area & Drasch et al. (2001) \\
\hline Negro river basin, Brazil & 21.40 & $1.7-59.0$ & Adults $>15 \mathrm{yr}$ & Barbosa et al. (2001) \\
\hline Germany & 0.23 & $0.06-1.7$ & $8-10$ yr old children & Pesch et al. (2002) \\
\hline \multirow[t]{2}{*}{ USA } & 0.22 & $0.18-0.25$ & $1-5 \mathrm{yr}$ old children, NHANES study & McDowell et al. (2004) \\
\hline & 0.47 & $0.35-0.58$ & 16-49 yr old women & \\
\hline USA & 0.29 & & $18-45$ yr old women child bearing age & Knobeloch et al. (2005) \\
\hline Aegean islands, Greece & 1.36 & $0.05-17.5$ & Women, mothers and children & Gibicar et al. (2006) \\
\hline Menorca, Spain & 0.72 & $0.23-3.83$ & 4 yr old children, diffuse source & Montuori et al. (2006) \\
\hline Flix, Spain & 1.26 & $0.19-5.63$ & 4 yr old children, chlor-alkali source & \\
\hline Naples, Italy & 0.64 & $0.22-3.40$ & Adults in urban area & Díez et al. (2008) \\
\hline Gorlovka, Ukraine & 3.95 & & Workers at a Hg recycling operation & Gibb et al. (2008) \\
\hline Florida, USA & 0.25 & $0.02-22.14$ & Women of child-bearing age & Karouna-Renier et al. (2008) \\
\hline Beni river, Bolivia & 3.76 & $0.42-15.65$ & Gold-mining area & Barbieri et al. (2009) \\
\hline Guizhou Province, China & 4.60 & $1.5-16$ & Wanshan $\mathrm{Hg}$ mining area & Li et al. (2009) \\
\hline Urban cities, Spain & 1.71 & $0.13-8.43$ & Newborns ( $>3$ months old) & Díez et al. (2009) \\
\hline Estarreja, Portugal & 1.5 & $0.09-4.2$ & Chlor-alkali source & Reis et al. (2009) \\
\hline Southern Sweden & 0.22 & $0.04-0.33$ & Pregnant women & Gerhardsson and Lundh (2010) \\
\hline Gulf of Gabes, Tunisia & 6.5 & $1.3-14$ & Adults, frequent fish consumers & Mezghani-Chaari et al. (2010) \\
\hline \multirow[t]{2}{*}{ Taiji, Japan } & 20.4 & $4.4-67.2$ & People who eat whale $\&$ dolphin meat & Endo and Haraguchi (2010) \\
\hline & 2.50 & $0.4-6.1$ & People who do not eat fish & \\
\hline Granada, Spain & 0.95 & & 4 yr old children & Freire et al. (2010) \\
\hline Slovenia & 0.39 & $0.015-2.08$ & Pregnant women & Miklavčič et al. (2011) \\
\hline \multirow{2}{*}{ ALM and CLM, Spain } & 3.15 & $0.45-9.35$ & Males & This study \\
\hline & 2.28 & $0.20-6.04$ & Females & \\
\hline Almadén area & 2.44 & $0.67-4.83$ & Women of child-bearing age & \\
\hline Castilla-La Mancha area & 1.73 & $0.20-5.56$ & Women of child-bearing age & \\
\hline
\end{tabular}


the consumption of fish does not increase the levels of $\mathrm{THg}$ as much as in CLM, where baseline levels of THg are much lower $(-0.217)$.

\section{Conclusions}

In our study, THg levels were determined in the scalp hair of residents close to a mercury hot spot (Almadén) and from another area far away. The mercury concentrations in the two groups were mainly related to age, gender and fish consumption. According to the results of the present study, individuals living close to the mining area of Almadén showed higher levels of mercury than the others. The results of the multiple regression model showed that even though the fish consumption frequency was one key parameter for the whole group, in the case of people living in Almadén, i.e. close to a high-impacted mercury area, exposure to mercury due to residence was a key determinant that contributed to increased mercury levels in the human body. Further studies are needed to elucidate if other local mercury-rich food products (e.g. red swamp crayfish, Asparagus acutifolius), besides fish, are determinants of mercury levels in the Almadén population.

In general, it can be concluded that the population most at risk is located in the vicinity of former mining activities, in the area of Almadén.

\section{Acknowledgements}

Funding from Spanish Ministry of Science and Innovation (Grants CTM2006-13091 and CGL2009-13171) and from CastillaLa Mancha regional government - Viceconsejería de Universidades e Investigación (Grant PII1I09-0142-4389) is acknowledged. Luis Mansilla Plaza (EUP Almadén) collaborated in the sampling process. Núria Ribas collaborated in the early data treatment.

\section{References}

Aks, S.E., Erickson, T., Branches, F.J.P., Naleway, C., Chou, H.N., Levy, P., et al., 1995 Mercury levels in Brazilian gold refiners and miners. J. Toxicol. Clin. Toxicol. 33 $1-10$

Babi, D., Vasjari, M., Celo, V., Koroveshi, M., 2000. Some results on Hg content in hair in different populations in Albania. Sci. Total Environ. 259, 55-60.

Barbieri, F.L., Cournil, A., Gardon, J., 2009. Mercury exposure in a high fish eating Bolivian Amazonian population with intense small scale gold-mining activities. Int. J. Environ. Health Res. 19, 267-277.

Barbosa, A.C., Jardim, W., Dorea, J.G., Fosberg, B., Souza, J., 2001. Hair mercury speciation as a function of gender, age, and body mass index in inhabitants of the Negro River basin, Amazon, Brazil. Arch. Environ. Contam. Toxicol. 40, 439 444.

Batista, J., Schuhmacher, M., Domingo, J.L., Corbella, J., 1996. Mercury in hair for child population from Tarragona Province, Spain. Sci. Total Environ. 193, 143148.

Bjornberg, K.A., Vahter, M., Grawe, K.P., Berglund, M., 2005. Methyl mercury exposure in Swedish women with high fish consumption. Sci. Total Environ. $341,45-52$

Burger, J., 2000. Gender differences in meal patterns: role of self-caught fish and wild game in meat and fish diets. Environ. Res. 83, 140-149.

Burger, J., 2005. Fishing, fish consumption, and knowledge about advisories in college students and others in central New Jersey. Environ. Res. 98, 268-275.

Cernichiari, E., Toribara, T.Y., Liang, L., Marsh, D.O., Berlin, M.W., Myers, G.J., et al. 1995. The biological monitoring of mercury in the Seychelles study. Neurotoxicology 16, 613-627.

Dakeishi, M., Nakai, K., Sakamoto, M., Iwata, T., Suzuki, K., Liu, X.J., Ohno, T. Kurosawa, $\mathrm{T}$, Satoh, $\mathrm{H}$. Murata, $\mathrm{K}$, 2005. Effects of hair treatment on hair mercury-the best biomarker of methylmercury exposure? Environ. Health Prevent. Med. 10, 208-212.

Díez, S., Montuori, P., Pagano, A., Sarnacchiaro, P., Bayona, J.M., Triassi, M., 2008 Hair mercury levels in an urban population from southern Italy: fish consumption as a determinant of exposure. Environ. Int. 34, 162-167.

Díez, S., Delgado, S., Aguilera, I., Astray, J., Pérez-Gómez, B., Torrent, M., Sunyer, J., Bayona, J.M., 2009. Prenatal and early childhood exposure to mercury and methylmercury in Spain, a high fish consumer country. Arch. Environ. Contam. Toxicol. 56, 615-622.

Díez, S., 2009. Human health effects of methylmercury exposure. Rev. Environ. Contam. Toxicol. 198, 111-132.
Drasch, G., Bose-O'Reilly, S., Beinhoff, C., Roider, G., Maydl, S., 2001. The Mt. Diwata study on the Philippines 1999: assessing mercury in toxication of the population by small scale gold mining. Sci. Total Environ. 267, 151-168.

Endo, T., Haraguchi, K., 2010. High mercury levels in hair samples from residents of Taiji, a Japanese whaling town. Mar. Pollut. Bull. 60, 743-747.

Freire, C., Ramos, R., Lopez-Espinosa, M.J., Díez, S., Vioque, J., Ballester, F., Fernández, M.F. 2010. Hair mercury levels, fish consumption, and cognitive development in preschool children from Granada, Spain. Environ. Res. 110, 96-104.

Gerhardsson, L., Lundh, T., 2010. Metal concentrations in blood and hair in pregnant females in Southern Sweden. J. Environ. Health 72, 37-41.

Gibb, H.J., Kozlov, K., Buckley, J.P., Centeno, J., Jurgenson, V., Kolker, A., Conko, K. Landa, E., Panov, B., Panov, Y., Xu, H., 2008. Biomarkers of mercury exposure at a mercury recycling facility in Ukraine. J. Occup. Environ. Hyg. 5, 483-489.

Gibicar, D., Horvat, M., Nakou, S., Sarafidou, J., Yager, J., 2006. Pilot study of intrauterine exposure to methylmercury in Eastern Aegean Islands, Greece. Sci. Total Environ. 367, 586-595.

Grandjean, P., Weihe, P., White, R.F., Debes, F., Araki, S., Yokoyama, K., Murata, K., Sorensen, N., Dahl, R., Jorgensen, P.J., 1997. Cognitive deficit in 7-year-old children with prenatal exposure to methylmercury. Neurotoxicol. Teratol. 19 417-428.

Grandjean, P., White, R.F., Nielsen, A., Cleary, D., de Oliveira Santos, E.C., 1999 Methylmercury neurotoxicity in Amazonian children: downstream from gold mining. Environ. Health Perspect. 107, 587-591.

Harada, M., Nakachi, S., Cheu, T., Hamada, H., Ono, Y., Tsuda, T., Yanagida, K., Kizaki, T., Ohno, H., 1999. Monitoring of mercury pollution in Tanzania: relation between head hair mercury and health. Sci. Total Environ. 227, 249-256.

Hernández, A., Jébrak, M., Higueras, P., Oyarzun, R., Morata, D., Munhá, J., 1999. The Almadén mercury mining district, Spain. Miner. Deposita 34, 539-548.

Higueras, P., Oyarzun, R., Lillo, J., Sánchez-Hernández, J.C., Molina, J.A., Esbrí, J.M., Lorenzo, S., 2006. The Almadén district (Spain): anatomy of one of the world's largest Hg-contaminated sites. Sci. Total Environ. 356, 112-124.

Holsbeek, L., Das, H.K., Joiris, C.R., 1996. Mercury in human hair and relation to fish consumption in Bangladesh. Sci. Total Environ. 186, 181-188.

Horvat, M., Nolde, N., Fajon, V., Jereb, V., Logar, M., Lojen, S., et al., 2003. Total mercury, methyl mercury and selenium in mercury polluted areas in the province Guizhou, China. Sci. Total Environ. 304, 231-256.

Johnsson, C., Sallsten, G., Schutz, A., Sjors, A., Barregard, L., 2004. Hair mercury level versus freshwater fish consumption in household members of Swedish angling societies. Environ. Res. 96, 257-263.

Johnsson, C., Schutz, A., Sallsten, G., 2005. Impact of consumption of freshwater fish on mercury levels in hair, blood, urine, and alveolar air. J. Toxicol. Environ. Health Part A 68, 129-140.

Karouna-Renier, N.K., Rao, K.R., Lanza, J.J., Rivers, S.D., Wilson, P.A., Hodges, D.K. Levine, K.E., Ross, G.T., 2008. Mercury levels and fish consumption practices in women of child-bearing age in the Florida Panhandle. Environ. Res. 108, 320-326.

Knobeloch, L., Anderson, H.A., Imm, P., Peters, D., Smith, A., 2005. Fish consumption, advisory awareness, and hair mercury levels among women of child bearing age. Environ. Res. 97, 220-227.

Knobeloch, L., Gliori, G., Anderson, H., 2007. Assessment of methylmercury exposure in Wisconsin. Environ. Res. 103, 205-210.

Kosatsky, T., Przybysz, R., Armstrong, B., 2000. Mercury exposure in Montrealers who eat St. Lawrence River sportfish. Environ. Res. 84, 36-43.

Lebel, J., Mergler, D., Lucotte, M., Amorim, M., Dolbec, J., Miranda, D., et al., 1996. Evidence of early nervous system dysfunction in Amazonian populations exposed to low-levels of methylmercury. Neurotoxicology 17, 157-167.

Lebel, J., Roulet, M., Mergler, D., Lucotte, M., Larribe, F., 1997. Fish diet and mercury exposure in a riparian Amazonian population. Water Air Soil Pollut. 97, 31-44.

i, P.,Feng X.B. Qiu, G. L, Shang L, Li, G, 2009. Human hair mercury levels in the Wanshan mercury mining area, Guizhou Province, China. Environ. Geochem. Health 31, 683-691.

Mahaffey, K.R., 2005. Mercury exposure: medical and public health issues. Trans. Am. Clin. Climatol. Assoc. 116, 128-153.

Malm, O., Branches, F.J.P., Akagi, H., Castro, M.B., Pfeiffer, W.C., Harada, M. et al. 1995. Mercury and methylmercury in fish and human hair from the Tapajos river basin, Brazil. Sci. Total Environ. 175, 141-150.

Martínez-Coronado, A., Oyarzun, R., Esbrí, J.M., Llanos, W., Higueras, P., in press. Sampling high to extremely high $\mathrm{Hg}$ concentrations at the Cerco de Almadenejos, Almadén mining district (Spain): the old metallurgical precinct (1794-1861 AD) and surrounding areas. J. Geochem. Explor. doi:10.1016/ j.gexplo.2010.04.007

McDowell, M.A., Dillon, C.F., Osterloh, J., Bolger, P.M., Pellizzari, E., Fernando, R., de Oca, R.M., Schober, S.E., Sinks, T., Jones, R.L., Mahaffey, K.R., 2004. Hair mercury levels in US children and women of child bearing age: reference range data from NHANES 1999-2000. Environ. Health Perspect. 112, 1165-1171.

Mezghani-Chaari, S., Hamza, A., Hamza-Chaffai, A., in press. Mercury contamination in human hair and some marine species from Sfax coasts of Tunisia: levels and risk assessment. Environ. Monit. Assess. doi:10.1007/s10661-010-1800-1.

Miklavčič, A., Stibilj, V., Heath, E., Polak, T., Tratnik, J.S., Klavž, J., Mazej, D., Horvat M., 2011. Mercury, selenium, PCBs and fatty acids in fresh and canned fish available on the Slovenian market. Food Chem. 124, 711-720.

Molina, J.A., Oyarzun, R., Esbrí, J.M., Higueras, P., 2006. Mercury accumulation in soils and plants in the Almadén mining district, Spain: one of the most contaminated sites on Earth. Environ. Geochem. Health 28, 487-498.

Montuori, P., Jover, E., Diez, S., Ribas-Fito, N., Sunyer, J., Triassi, M., Bayona, J.M., 2006. Mercury speciation in the hair of pre-school children living near a chloralkali plant. Sci. Total Environ. 369, 51-58. 
Moreno, T., Higueras, P., Jones, T., McDonald, I., Gibbons, W., 2005. Size fractionation in mercury-bearing airborne particles $\left(\mathrm{HgPM}_{10}\right)$ at Almadén, Spain: implications for inhalation hazards around old mines. Atmos. Environ. 39, 6409-6419.

Morrissette, J., Takser, L., St-Amour, G., Smargiassi, A., Lafond, J., Mergler, D., 2004. Temporal variation of blood and hair mercury levels in pregnancy in relation to fish consumption history in a population living along the St. Lawrence River. Environ. Res. 95, 363-374.

Mortada, W.I., Sobh, M.A., El-Defrawy, M.M., Farahat, S.E., 2002. Reference intervals of cadmium, lead, and mercury in blood, urine, hair, and nails among residents in Mansoura city, Nile delta, Egypt. Environ. Res. 90, 104-110.

Myers, G.J., Davidson, P.W., Cox, C., Shamlaye, C., Cernichiari, E., Clarkson, T.W., 2000. Twenty-seven years studying the human neurotoxicity of methyl mercury exposure. Environ. Res. 83, 275-285.

Nakagawa, R., 1995. Concentration of mercury in hair of Japanese people. Chemosphere 30, 127-133.

Olivero, J., Jonson, B., Arguello, E., 2002. Human exposure to mercury in San Jorge river basin, Colombia (South America). Sci. Total Environ. 289, 41-47.

NationalResearchCouncil (NRC), 2000. Committee on the Toxicological Effects of Methyl Mercury. National Academies Press, Wahshington, DC.

Pesch, A., Wilhelm, M., Rostek, U., Schmitz, N., Weishoff-Houben, M., Ranft, U., Idel, H., 2002. Mercury concentrations in urine, scalp hair, and saliva in children from Germany. J. Exp. Anal. Environ. Epidemiol. 12, 252-258.
Phelps, R.W., Clarkson, T.W., Kershaw, T.G., Wheatley, B., 1980. Interrelationships of blood and hair mercury concentrations in a north-american population exposed to methylmercury. Arch. Environ. Health 35, 161-168.

PRTR - Registro Estatal de Emisiones y Fuentes Contaminantes, Spanish Ministry of Environment, 2011. <http://www.en.prtr-es.es/> (accessed February 2011).

Reis, A.T., Rodrigues, S.M., Araújo, C., Coelho, J.P., Pereira, E., Duarte, A.C., 2009. Mercury contamination in the vicinity of a chlor-alkali plant and potential risks to local population. Sci. Total Environ. 407, 2689-2700.

Renzoni, A., Zino, F., Franchi, E., 1998. Mercury levels along the food chain and risk for exposed populations. Environ. Res. 77, 68-72.

Sholupov, S.E., Ganeyev, A.A., 1995. Zeeman atomic-absorption spectrometry using high-frequency modulated light polarization. Spectrochim. Acta Part B 50, 1227-1236.

Smith, J.C., Farris, F.F., 1996. Methyl mercury pharmacokinetics in man: a reevaluation. Toxicol. Appl. Pharmacol. 137, 245-252.

USEPA, 2001. Water Quality Criterion for the Protection of Human Health: Methylmercury. <http://www.epa.gov/waterscience/criteria/methylmercury/ document.html> (accessed February 2011).

USEPA, 2010. Guidance for Implementing the January 2001 Methylmercury Water Quality Criterion. EPA 823-R-10-001. US Environmental Protection Agency, Office of Water, Washington, DC.

WHO, 1990. World Health Organisation. International Programme on Chemical Safety. Environmental Health Criteria 101: Methyl mercury. WHO, Geneva. 